\title{
Orotracheal tube versus supraglottic devices in biological, chemical and radiological disasters: meta-analysis in manikin-based studies
}

\author{
Tubo orotraqueal versus dispositivos supraglóticos em desastres biológicos, químicos e radiológicos: \\ metanálise em estudos com manequim \\ Tubo orotraqueal versus dispositivos supraglóticos en desastres biológicos, químicos y radiológicos: \\ metaanálisis en estudios de maniquíes
}

\section{Israel Baptista de Souza Borges' ORCID: 0000-0002-7083-3580 \\ Magali Rezende de Carvalho" ORCID: 0000-0002-2261-5570 \\ Marcel de Souza Quintana"'I ORCID: 0000-0001-5186-9791}

Dalmo Valério Machado de Lima" ORCID: 0000-0003-3587-6224

Bruno Leal Barbosa' ORCID: 0000-0001-6042-2721

Alexandre Barbosa de Oliveira' ORCID: 0000-0003-4611-1200

'Universidade Federal do Rio de Janeiro. Rio de Janeiro, Rio de Janeiro, Brazil. "Universidade Federal Fluminense. Niterói, Rio de Janeiro, Brazil. "'Fundação Oswaldo Cruz. Rio de Janeiro, Rio de Janeiro, Brazil.

How to cite this article: Borges IBS, Carvalho MR, Quintana MS, Lima DVM, Barbosa BL, Oliveira AB. Orotracheal tube versus supraglottic devices in biological, chemical and radiological disasters: meta-analysis in manikin-based studies. Rev Bras Enferm. 2020;74(5):e20200313. https://doi.org/10.1590/0034-7167-2020-0313

Corresponding Author: Israel Baptista de Souza Borges E-mail: israelbsborges@gmail.com

EDITOR IN CHIEF: Dulce Barbosa ASSOCIATE EDITOR: Marcia Magro

Submission: 07-18-2020

Approval: 04-02-2021

\section{ABSTRACT}

Objective: To compare the mean time of orotracheal intubation and insertion of supraglottic airway devices, considering healthcare providers wearing waterproof overall, gloves, boots, eye protection and mask at the Chemical, Biological, Radiological and Nuclear context in simulation setting. Methods: Six databases were searched. The selected studies were put in a pool of results using a random-effects meta-analysis, with standardized mean differences and calculation of 95\% confidence intervals. Results: Nine observational studies were included. Regarding reducing time to provide ventilatory support, subgroup analyses were made. The emergency setting subgroup: $-12.97[-16.11 ;-9.83] ;\left.\right|^{2}=64 \%$. The surgery setting subgroup:-14.96 [-18.65;-11.27]; $\left.\right|^{2}=75 \%$. Another analysis was made by reproductive methodology subgroups. Ophir's subgroup: -15.70 [-17.04; -14.37]; $\left.\right|^{2}=0 \%$. All meta-analyses had orotracheal tube as comparator. Conclusion: Moderate level of evidence was in favor of insertion of supraglottic devices because of fast application. Descriptors: Meta-Analysis; Personal Protective Equipment; Laryngeal Masks; Disasters; Manikins.

\section{RESUMO}

Objetivo: Comparar o tempo médio de intubação orotraqueal e inserção de dispositivos supraglóticos das vias aéreas, considerando profissionais de saúde vestindo macacão impermeável luvas, botas, proteção ocular e máscara no contexto Químico, Biológico, Radiológico e Nuclear em cenário de simulação. Métodos: Seis bases de dados foram pesquisadas. Os estudos selecionados foram colocados em um conjunto de resultados usando uma metanálise de efeitos aleatórios com diferenças médias padronizadas e cálculo de intervalos de confiança de $95 \%$. Resultados: Nove estudos observacionais foram incluídos. Com relação à redução do tempo para fornecer suporte ventilatório, foram feitas análises de subgrupos. O subgrupo do ambiente de emergência: $-12,97[-16,11 ;-9,83] ;\left.\right|^{2}=64 \%$. O subgrupo do ambiente de cirurgia:-14,96 [-18,65;-11,27]; $1^{2}=75 \%$. Outra análise foi feita por subgrupos de metodologia reprodutiva. Subgrupo de Ophir: $-15,70[-17,04 ;-14,37] ;\left.\right|^{2}=0 \%$. Em todas as metanálises, 0 tubo orotraqueal foi usado como comparador. Conclusão: Nível moderado de evidência a favor da inserção de dispositivos supraglóticos por sua aplicação mais rápida.

Descritores: Metanálise; Equipamento de Proteção Individual; Máscaras Laríngeas; Desastres; Manequins.

\section{RESUMEN}

Objetivo: Comparar el tiempo medio de intubación orotraqueal e inserción de dispositivos de vía aérea supraglótica, considerando profesionales de la salud con overol impermeable, guantes, botas, protección ocular y mascarilla en el contexto químico, biológico, radiológico y nuclear en un escenario de simulación. Métodos: Se realizaron búsquedas en seis bases de datos. Los estudios seleccionados se pusieron en un conjunto de resultados mediante un metaanálisis de efectos aleatorios con diferencias de medias estandarizadas y cálculo de intervalos de confianza del 95\%. Resultados: Se incluyeron nueve estudios observacionales. Con respecto a la reducción del tiempo para proporcionar soporte ventilatorio, se realizaron análisis de subgrupos. El subgrupo del entorno de emergencia: $-12,97[-16,11 ;-9,83] ;\left.\right|^{2}=64 \%$. El subgrupo del entorno quirúrgico: $-14,96[-18,65 ;-11,27] ;\left.\right|^{2}=75 \%$. Otro análisis fue realizado por subgrupos de la metodología reproductiva. Subgrupo Ophir:-15,70 [-17,04;-14,37]; $\left.\right|^{2}=0 \%$. En todos los metaanálisis, se utilizó el tubo orotraqueal como comparador. Conclusión: Nivel de evidencia moderado a favor de la inserción de dispositivos supraglóticos debido a la aplicación más rápida.

Descriptores: Metaanálisis; Equipo de Protección Personal; Máscaras Laríngeas; Disasters; Maniquíes. 


\section{INTRODUCTION}

Certain emergencies involving chemical, biological, or radiological agents may cause acute respiratory failure. Rescuers should use appropriate personal protective equipment to prevent secondary contamination until victims are decontaminated. Otherwise, they may become new victims and unable to help. This occurred on the subway in Tokyo, in 1995, when 135 healthcare providers were intoxicated with Sarin neurotoxic gas while they assisted victims ${ }^{(1)}$.

Concerning biological agents, professionals who provide direct assistance to patients have suffered an unprecedented impact in the fight against coronavirus (COVID-19) worldwide. Despite all restrictive measures adopted by the general population, healthcare providers enter into their work units exposing themselves to risk of contamination during their duties ${ }^{(2)}$. This led to a specific preparation by healthcare providers to use personal protective equipment as well as transportation procedures and directed assistance to patients ${ }^{(3)}$. These precautions are justified by the high infectivity rate of COVID-19, by the pathophysiology of the disease that has the potential to develop pneumonia and an acute respiratory failure ${ }^{(4)}$.

Regarding an accident with multiple victims with involvement of radiological agents, it can be said that victims who are exposed to whole-body radiation doses between 2 to 12 grey are more likely to survive, but they are likely to present functional impairment in the skin, lungs, gastrointestinal tract, and bone marrow $^{(5)}$. At these moments, short-term interventions have to be aimed at saving lives, such as airway management. However, the lack of knowledge and adequate training by healthcare providers regarding the victims of radiological contamination is a complicating factor ${ }^{(6)}$.

In accidents of this nature in the civil environment, contaminated victims can go to hospital units without first treatment on site, where some important actions, such as decontamination, should be taken. Thus, healthcare providers working in the emergency, both in the pre-hospital and in-hospital field, performing life support and screening procedures to identify victims who require urgent medical treatment, have an important role ${ }^{(7)}$. Serious situations related to traumatic injuries, chemical intoxication, radiation or infection, sometimes only allow for a brief decontamination by removal of the victim's robes before conducting emergency and surgical procedures. In this context, at least Level C personal protective equipment, consisting essentially of a waterproof overall, gloves, boots, eye protection and mask, is recommended ${ }^{(1-2,8-9)}$. There are other types of attire that imply higher level of safety, such as Level A and B. To describe properly, Level A personal protective equipment is a fully encapsulated and chemically resistant suit with integral gloves and boots that requires the use of self-contained breathing apparatus. It provides the maximal amount of vapor and splash protection. Level B personal protective equipment is a chemically resistant suit, gloves and boots not integrated, with a positive pressure, full-faced respirator connected to self-contained breathing apparatus. It offers less protection against skin, eye and mucous membrane exposure compared with Level A, it is not encapsulated and should be used where liquids or particles present are known not to contain high level of chemicals harmful. Thus, comparing the use of Level A, B and $C$ personal protective equipment by health providers, Level $C$ personal protective equipment has been largely used for its efficacy, operational use, practical reasons of mobility and time reduced performing health procedures ${ }^{(9)}$.

As a basic principle, once signs and symptoms of severe respiratory failure, such as cyanosis, tachydyspnea and mental confusion have been identified in victims, orotracheal intubation and the insertion of supraglottic devices must be done for establishment of a patent airway and, consequently, decrease the risk of death ${ }^{(10-11)}$.

A literature review on ventilatory support techniques in biological, chemical or radiological disasters brought studies that have pointed to the benefit of orotracheal intubation ${ }^{(12-14)}$. On the other hand, there are studies that recommend the insertion of supraglottic devices ${ }^{(15-17)}$. For this reason, a meta-analysis was deemed necessary because it is understood that shorter time to implement the ventilatory support technique directly impacts the survival of victims in respiratory failure in a tragic setting. This analysis would provide substantial support for decision-making by healthcare providers about which technology to use as a priority. The research question was: what is the mean time to perform ventilatory support techniques for insertion of supraglottic device compared to orotracheal intubation, considering the use of Level $C$ personal protective equipment by healthcare providers in a simulation setting?

\section{OBJECTIVE}

To compare the mean time of orotracheal intubation and insertion of supraglottic devices, considering the use of Level $C$ personal protective equipment by healthcare providers at the Chemical, Biological, Radiological and Nuclear context in simulation setting.

\section{METHODS}

This systematic review and meta-analysis of the Prospective Register of Systematic Reviews (PROSPERO), CRD42019136139, followed the guidelines advocated by the Preferred Reporting Items for Systematic Reviews and Meta-Analyses (PRISMA). We used the MEDLINE, Scopus, Cochrane, Web of Science, LILACS and CINAHL databases, plus manual searches of reference lists of selected studies; search in the list of studies related to each eligible study on the PubMed platform and; search in the Google Scholar. Observational trials comparing orotracheal intubation with supraglottic devices performed in manikins by healthcare professionals using Level C Personal Protective Equipment were included. Observational trials comparing intubation with supraglottic devices performed by healthcare providers who used Level C Personal Protective Equipment on children or pediatric mannequins and, studies that did not provide the necessary data for meta-analysis, such as number of participants, mean time and standard deviation were excluded. The collection of studies occurred from March 8 to December 16, 2019, and there were no restrictions as to language or period of publication. The search strategies applied are as follows: 
LILACS: respiratory failure [subject descriptor] and personal protective equipment [subject descriptor] or laryngeal mask [words].

CINAHL: ((MM"Respiratory Failure+") OR ("manikin") OR (MM "Chemical Warfare Agents")) AND ((MM "Self Defense Agents, Chemical") OR (MM“Laryngoscopy") OR (MM“Laryngeal Masks")).

MEDLINE: ((()((respiratory insufficiency [MeSH Terms]) OR manikins [MeSH Terms]) OR nerve agents [MeSH Terms]) OR chemical warfare agents [MeSH Terms]) OR hazardous substances [MeSH Terms])) AND (((((airway management [MeSH Terms]) OR intubation, Intratracheal [MeSH Terms]) OR Personal Protective Equipment [MeSH Terms]) OR protective clothing [MeSH Terms]) OR laryngoscopy [MeSH Terms])) AND laryngeal masks [MeSH Terms].

Scopus: (TITLE-ABS-KEY (airway AND management) OR TITLEABS-KEY (manikin*) ANDTITLE-ABS-KEY (personal AND protective AND equipment) OR TITLE-ABS-KEY (cbrn) OR TITLE-ABS-KEY (cbrn AND ppe) OR TITLE-ABS-KEY (chemical AND suit) OR TITLE-ABSKEY (protective AND clothing) AND TITLE-ABS-KEY (intubation)).

Cochrane: (airway*): ti,ab,kw AND (intubation*):ti,ab,kw AND ("personal protective equipment"*):ti,ab,kw OR (protective clothing*):ti,ab,kw AND (laryngeal mask*):ti,ab,kw.

Web of Science: ALL FIELDS: (airway management) ANDTITLE: (manikin*) OR TITLE: (cadaver*) AND TITLE: (personal protective equipment) OR TITLE: (CBRN-PPE) AND ALL FIELDS: (intubation) AND ALL FIELDS: (laryngeal mask*) OR ALL FIELDS: (supraglottic). Refined by:WEB OF SCIENCE CATEGORIES: (EMERGENCY MEDICINE).

The studies were selected by two independent reviewers (IBSB and LRR), who screened studies by reading titles and abstracts, with due registration in the eligibility form. A Kappa coefficient of 0.74 was obtained after analysis of the lists, a satisfactory value reflecting the objectivity and clarity of the data to be collected ${ }^{(18)}$. Disagreements regarding the inclusion of studies were resolved reaching an agreement. Then, the citations were exported to EndNote online reference manager. All studies from this first selection had full text analysis. The data collected from each study were organized in a data extraction instrument containing: name of the authors; title; country of origin; year and journal of publication; study population and environment; types of ventilatory support devices; number of participants; mean time spent; standard deviation.

According to the Risk of Bias In Non-randomized Studies of Interventions (ROBINS-I), each eligible study was classified as low, moderate, serious, critical risk of bias and no information ${ }^{(19)}$. Meta-analyses were run using the RevMan 5.3 software, through a random-effect approach, with calculation of the difference of time means. The risk of publication bias was assessed through the creation and assessment of the funnel plot. All meta-analyses were presented in order of effect of the studies. When a study did not present all data for meta-analysis, but offered ways to calculate it, the data were calculated. Low heterogeneity was considered when the $\mathrm{I}^{2}$ test was < $50 \%$; moderate heterogeneity, when the $I^{2}$ test was between 50 and $75 \%$; high heterogeneity, when the $I^{2}$ test was $>75 \%{ }^{(20)}$. Additionally, the analysis was treated by subgroups when $\mathrm{I}^{2}>50 \%$. A significance level of 0.05 was adopted. The GRADE system was used to assess the quality of evidence classified as high, moderate, low and very low ${ }^{(21)}$.

\section{RESULTS}

Figure 1 presents the product of the search strategies employed.

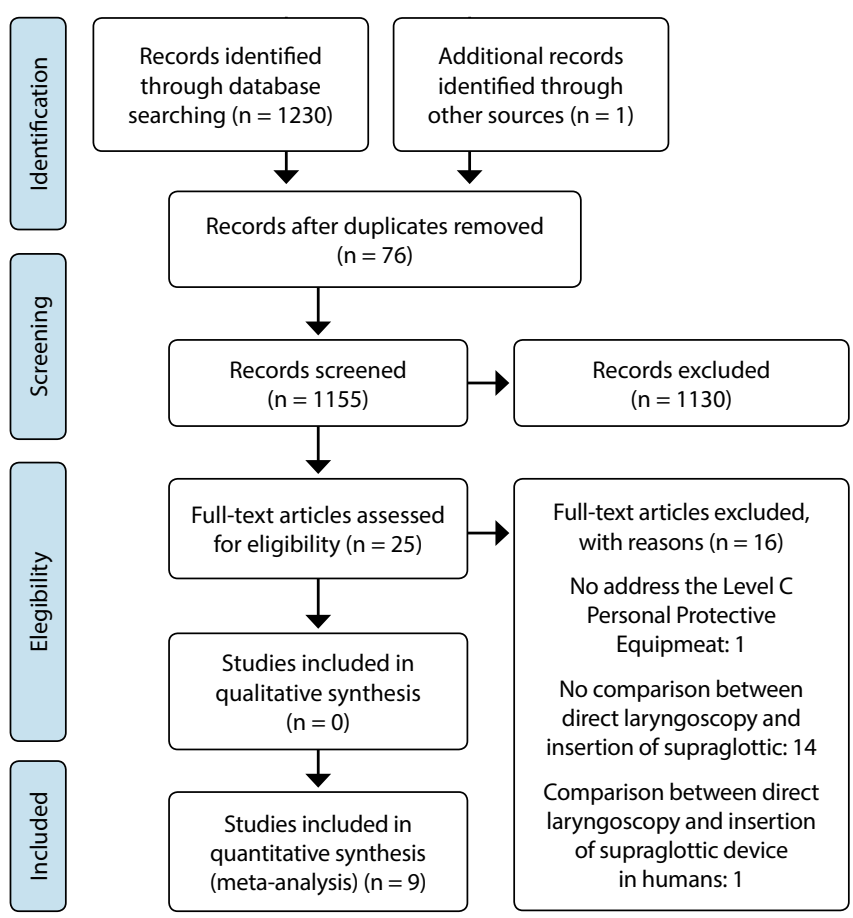

Figure 1- Flowchart of the Systematic Review in PRISMA format

Chart 1 characterizes the nine studies included in the metaanalysis, all of which were prospective, of observational type.

The search in six databases resulted in collecting studies from different countries around the world: Australia ${ }^{(9,25)}$, Israel ${ }^{(22,26)}$, Switzerland ${ }^{(15)}$, Taiwan ${ }^{(16)}$, United Kingdom ${ }^{(23-24)}$, and United States of America ${ }^{(27)}$.

The quality of each selected study was assessed through the Risk of Bias In Non-randomized Studies of Interventions (ROBINS-I) tool. Pre-intervention, intervention and post-intervention domains were assessed $^{(19)}$. The final classification of the study was based on the highest risk of bias found among the domains. Considering the observational design to the included studies, the risk of bias due to bias to confounding was moderate risk. since the participants performed as supraglottic devices as orotracheal tube ${ }^{(28)}$. Low risk was attributed to bias in selection of participants. Concerning bias in classification of interventions, low risk was considered due to well-defined intervention status, achieve success in a ventilatory support or not. There were differences between the experimental interventions since some participants failed the intubation and insertion of supraglottic devices, which resulted in a moderate risk of bias due to deviations from intended interventions. Low risk of attrition detection bias was attributed to the studies due to textual evidence within the study and further explanation provided by the author via email.

Regarding the reporting bias, a low risk of bias was attributed because no indication of attempted data manipulation was identified. The overall judgement assessed was a moderate risk decreased by bias to confounding and bias due to deviations from intended interventions. 
Chart 1 - Characterization of the studies selected

\begin{tabular}{|c|c|c|c|c|}
\hline $\begin{array}{l}\text { Authors } \\
\text { (Year) }\end{array}$ & Device & $\begin{array}{l}\text { Participants } \\
\text { (number) }\end{array}$ & $\begin{array}{l}\text { Success assessment } \\
\text { method }\end{array}$ & $\begin{array}{l}\text { Time limit } \\
\text { (seconds) }\end{array}$ \\
\hline $\begin{array}{l}\text { Ben-Abraham; } \\
\text { Weinbroum } \\
\text { (2004) }\end{array}$ & $\begin{array}{l}\text { Laryngeal Mask not specified; } \\
\text { Orotracheal tube }\end{array}$ & $\begin{array}{l}\text { Healthcare provider non-anesthetist (10); } \\
\text { Anesthetist (10) }\end{array}$ & $\begin{array}{l}\text { Expansion of the } \\
\text { mannequin's lung }\end{array}$ & 30 \\
\hline $\begin{array}{l}\text { Castle et } a^{(23)} \\
(2009)\end{array}$ & $\begin{array}{l}\text { Laryngeal Mask not specified; } \\
\text { Orotracheal tube }\end{array}$ & $\begin{array}{l}\text { Pre-hospital care doctors (4); } \\
\text { Resuscitation officers (6); Paramedics (14); } \\
\text { Anesthetists (15); } \\
\text { Emergency physicians (25). }\end{array}$ & Capnography & 150 \\
\hline $\begin{array}{l}\text { Castle et al }(1)^{(24)} \\
(2010)\end{array}$ & $\begin{array}{l}\text { Laryngeal Mask not specified; } \\
\text { Orotracheal tube }\end{array}$ & $\begin{array}{l}\text { Anesthetist consultants (5); Anesthetist trainee } \\
\text { (10); Emergency physician consultant (8); } \\
\text { Emergency physician trainee (17); Prehospital } \\
\text { care doctor (4); Paramedic (17); } \\
\text { Resuscitation officer (6) }\end{array}$ & Capnography & Not reported \\
\hline $\begin{array}{l}\text { Garner; Laurence; } \\
\text { Lee }^{(9)} \\
(2004)\end{array}$ & $\begin{array}{l}\text { Laryngeal Mask not specified; } \\
\text { Orotracheal tube }\end{array}$ & $\begin{array}{l}\text { Paramedics (3); } \\
\text { Emergency physicians (3); } \\
\text { Anesthetists (2). }\end{array}$ & $\begin{array}{l}\text { Expansion of the } \\
\text { mannequin's lung }\end{array}$ & Not reported \\
\hline $\begin{array}{l}\text { Greenland et } a^{(25)} \\
(2007)\end{array}$ & $\begin{array}{l}\text { Intubating Laryngeal Mask; } \\
\text { Orotracheal tube }\end{array}$ & $\begin{array}{l}\text { Consultant anesthetists (04); Anesthetist } \\
\text { trainees (14) }\end{array}$ & $\begin{array}{l}\text { Expansion of the } \\
\text { mannequin's lung }\end{array}$ & Not reported \\
\hline $\begin{array}{l}\text { Ophir et al(26) } \\
\text { (2014) }\end{array}$ & $\begin{array}{l}\text { Laryngeal Mask } \\
\text { Unique; } \\
\text { Laryngeal Mask } \\
\text { Supreme; } \\
\text { Laryngeal tube Suction - Disposal; } \\
\text { Orotracheal tube }\end{array}$ & $\begin{array}{l}\text { Anesthetist (20); } \\
\text { Medic (26), Paramedic (27), } \\
\text { General practitioners (24); } \\
\text { Residents (20) }\end{array}$ & $\begin{array}{l}\text { Expansion of the } \\
\text { mannequin's lung }\end{array}$ & Not reported \\
\hline $\begin{array}{l}\text { Plazikowski et a/ }{ }^{(15)} \\
\text { (2018) }\end{array}$ & $\begin{array}{l}\text { i-gel; } \\
\text { Intubating Laryngeal Mask; } \\
\text { Orotracheal tube }\end{array}$ & $\begin{array}{l}\text { Physician qualified as anesthetist and } \\
\text { emergencist (30) }\end{array}$ & $\begin{array}{l}\text { Expansion of the } \\
\text { mannequin's lung }\end{array}$ & 240 \\
\hline $\begin{array}{l}\text { Wang et } a^{(16)} \\
(2016)\end{array}$ & $\begin{array}{l}\text { Laryngeal Mask not specified; } \\
\text { Orotracheal tube }\end{array}$ & Emergency physician consultant and trainee (40) & $\begin{array}{l}\text { Expansion of the } \\
\text { mannequin's lung }\end{array}$ & Not reported \\
\hline $\begin{array}{l}\text { Weaver et al(27) } \\
(2015)\end{array}$ & $\begin{array}{l}\text { Intubating Laryngeal Mask; } \\
\text { Orotracheal tube }\end{array}$ & Emergency physician trainee (37) & $\begin{array}{l}\text { Expansion of the } \\
\text { mannequin's lung }\end{array}$ & Not reported \\
\hline
\end{tabular}

In order to assess the risk of publication bias, Figure 2 presents the degree of dispersion and the effect of intervention on the selected studies through the funnel plot. The circles represent the eligible studies. The higher the circle from the vertical axis, the smaller the standard error, more precision to calculate the mean of participants of each study and reliable confidence interval which imply a robust study. However, the existence of space between the circles can demonstrate publication bias.

According to Figure 3, it is observed that the technique of insertion of supraglottic devices barely indicated a lower mean time compared to the technique of orotracheal intubation with orotracheal tube.

After finding heterogeneity between studies, the reasons for such heterogeneity were sought. Among the reasons, it was observed a variety of healthcare providers as participants in the selected primary studies, as shown in Chart 1.Thus, in order to reduce heterogeneity, a subgroup analysis was performed ${ }^{(29)}$. Firstly, subgroups were generated according to the setting of activity of the study participants: emergency and surgery room. The emergency personnel subgroup comprised first responders, paramedics, and physicians. The creation of this subgroup resulted in decreased heterogeneity and significant overall effect among studies $(P<0.00001)$, which may have favored the supraglottic device, as shown in Figure 3.
In relation to the surgery personnel subgroup, including anesthetists, there was also a reduction in heterogeneity, with significant overall effect among studies, favoring supraglottic devices, as shown in Figure 3.

Another point to note was the observation that studies by Ophir et $\mathrm{al}^{(26)}$ and Plazikowski et $\mathrm{al}^{(15)}$ compared more than one supraglottic device with the orotracheal tube. That is, a methodology was replicated for different ventilatory support devices. This review considered the main function of the supraglottic devices: provide ventilatory support until the victims have clinical conditions to be intubated by orotracheal tube or spontaneous breathing recovery. The orotracheal tube is considered the most secure and definitive way to offer ventilatory support ${ }^{(12)}$. In addition to that, Table 1 and the meta-analysis present types of laryngeal masks described in the primary studies. From the perspective of methodological reproduction, two distinct studies by the same author, Castle et al $^{(23-24)}$, were analyzed. Thus, the creation of subgroups that presented this characteristic of methodological reproduction aimed to reduce data heterogeneity, as shown in Figure 4.

Given the results, following the methodology of this systematic review, the GRADE system was used to assess the quality of evidence in the outcome reduction of time to perform orotracheal intubation compared to insertion of supraglottic devices, 
considering health providers wearing Level $\mathrm{C}$ personal protective equipment in pre-hospital and hospital settings. Based on the nine observational studies, considering the 812 performances of ventilatory procedures, the mean time to perform orotracheal intubation was 41.19 seconds and the mean time to perform insertion of supraglottic devices was 19.39 seconds. Concerning data inconsistency, there was moderate heterogeneity among studies included in this review. However, the analysis for the outcome subgroup was statistically significant in favor of supraglottic devices. Related to risk of bias, there was lack of allocation concealment or lack of blinding. There was no difference about indirectness of evidence. Under analysis of imprecision of the confidence interval, the mean difference was -22.11 [-27.43, -16.79]. No publication bias was found. As supplemental consideration, it was found one study applied to human beings presenting results in favor of supraglottic device. Summarizing, the quality of the evidence of this review is moderate due to data inconsistency.

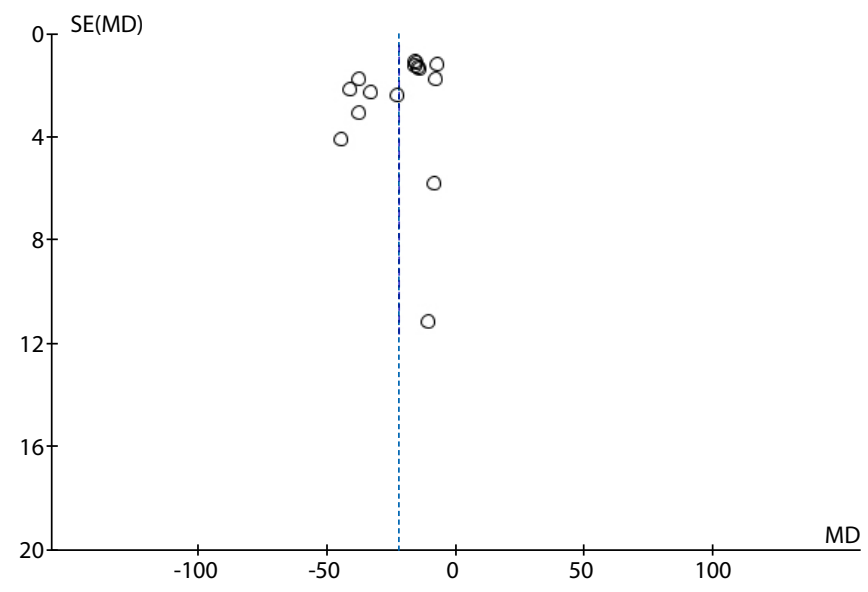

Figure 2 - Assessment of publication bias

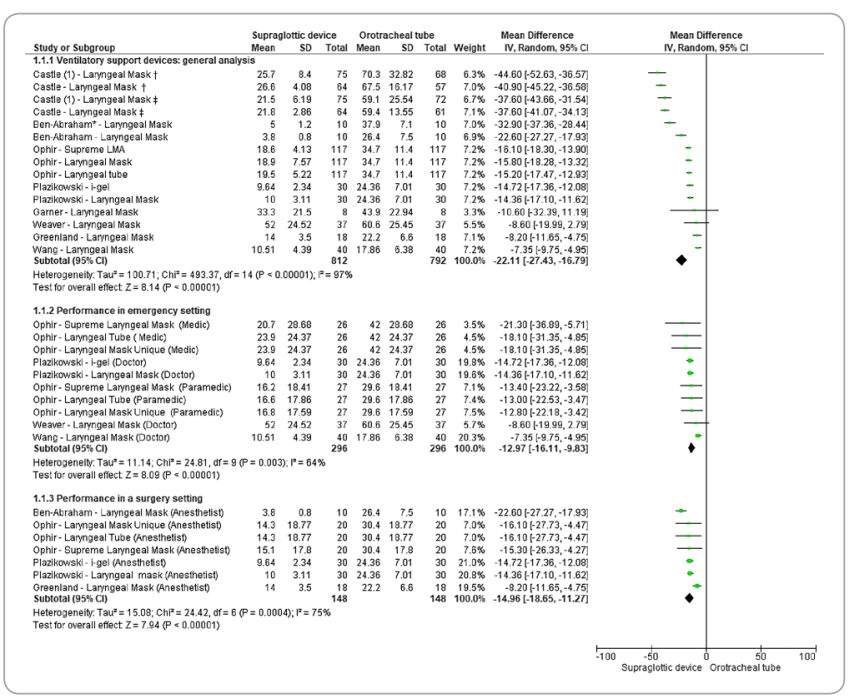

Note:

†- first attempt

₹ - second attempt

* - non-anesthetist

Figure 3 - Mean time of orotracheal intubation and insertion of supraglottic devices

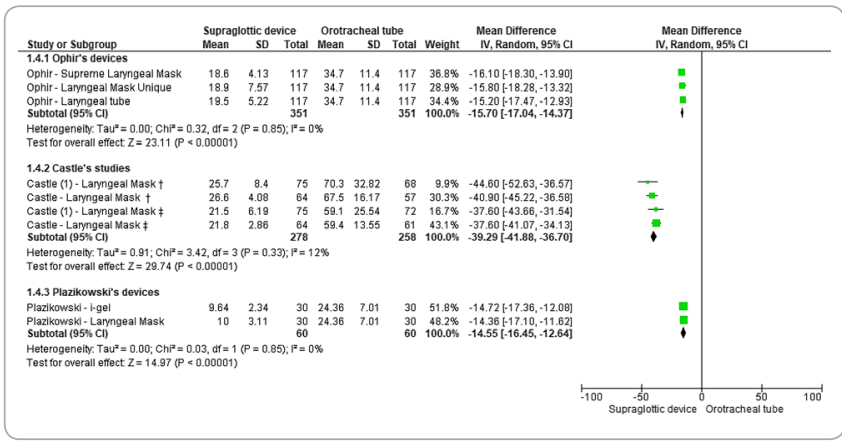

Note:

† - first attempt

₹- second attempt

Figure 4 - Reproductive methodology subgroups

\section{DISCUSSION}

In the case of an accident setting with multiple victims, one of the objectives is to provide a clear airway for as many people as possible ${ }^{(17,30)}$. Supraglottic devices used by healthcare providers with personal protective equipment in the biological, chemical or radiological environment have been studied in several countries, and the results have pointed to ease of use and speed of insertion. Moreover, it was observed that the training requirements for insertion of supraglottic devices are less strict when compared to orotracheal intubation ${ }^{(17,31)}$.

Another aspect that stood out concerns the clinical conditions of severely contaminated victims who require advanced life support, which includes ventilatory support, a priority for reducing mortality ${ }^{(28)}$. Even in such cases, orotracheal intubation is a gold standard to ensure clear airway and prevent death ${ }^{(32)}$. Emphasis should be given to the fact that emergency orotracheal intubation outside the operating room is related to significant challenges, including a higher incidence of difficult intubation due to possible environmental factors, lack of experience in orotracheal intubation, rapid deterioration of the clinical condition, and risk of regurgitation ${ }^{(11)}$.

For the outcome "reduction of the time spent in each procedure", the systematic review pointed out that the mean time to insert supraglottic devices is shorter compared to the orotracheal tube. At first sight, high heterogeneity was found, which questioned the results. The pool of health providers and the variety of supraglottic devices included in the primary studies may have affected the heterogeneity found. Subgroups by professional setting reduced the heterogeneity from high to moderate levels. An analysis by subgroups taking into consideration the professional area was performed by a statistician to calculate the standard deviation per professional class in the study by Ophir et $\mathrm{al}^{(26)}$. This measure enabled creating the subgroup of professionals of the emergency setting as it individualized data collection from first responders and paramedics, which was initially mixed with data from general medical classes and medical residents of various specialties. On the studies conducted by Castle et $\mathrm{al}^{(23-24)}$ and Garner, Laurence, Lee ${ }^{(9)}$, who had participants from various areas, it was not possible to present their data separating professional classes.

There was a study by Plazikowski et al. that used anesthetists who were actively working in the in-hospital emergency and air ambulance area ${ }^{(15)}$. This generated an impasse in which subgroup 
they should be allocated. This study was allocated in both subgroups since it cannot be ignored that studies point to the shorter execution times of ventilatory support techniques performed by anesthetists ${ }^{(22,26)}$. Moreover, it was observed that the removal of this study ${ }^{(15)}$ from the emergency setting subgroup reduced heterogeneity from $64 \%$ to $29 \%$ in the $\mathrm{I}^{2}$ test, which denotes the atypical condition of this study by having anesthetists working in the emergency area. Of the studies collected in the emergency setting subgroup, this study in particular ${ }^{(15)}$ presented the shortest time for insertion of supraglottic devices than the others, which contributed mainly to heterogeneity.

Another important analysis was the creation of subgroups with studies that assessed more than one supraglottic device compared to orotracheal tube, thus conferring a reproductive characteristic of the methodology. The methodological variation of each study is known to have a direct impact on the heterogeneity of data for meta-analyses ${ }^{(29,33)}$. Low heterogeneity $(0<$ $12<12 \%)$ and statistically significant results were obtained in the methodological reproduction subgroups, corroborating the previous analyses. Figure 4, as a complementary analysis, shows how the reproductive methodology can potentially reduce the heterogeneity of results, even including a variety of healthcare providers and supraglottic devices.

Regarding assessment of publication bias, it is known that methodological rigor and quality influence the asymmetry of the funnel plot $^{(29)}$. For this reason, it should be emphasized that Figure 2 shows a low risk of publication bias among the studies of this review. Additionally, there was a predominance of studies with high effect on the assessed intervention.

Regarding assessment of the level of evidence presented in the studies based on the GRADE system, under the outcome reduction of time for orotracheal intubation compared to insertion of supraglottic device, a moderate level of evidence was found favoring supraglottic devices.

\section{Limitations of the Study}

It is important to highlight that this systematic review assessed different types of supraglottic devices, as well as different methodologies, professional categories or areas of activity, and this reflected in heterogeneity. Potential factors causing heterogeneity were identified between studies. For instance, the number of performances with each device per study and the maximum time allowed to perform the procedure. Such information was sometimes not reported, which hindered a detailed analysis. However, the overall effect was favorable to supraglottic devices in all meta-analyses.

Another limitation concerns the instruments where ventilatory support techniques were applied. As explained in Table 1 on the characterization of eligible studies, this review focused on studies where healthcare providers performed techniques on manikins. However, it is noteworthy the case of an Israeli study that assessed orotracheal intubation and insertion of supraglottic devices in 60 humans submitted to surgical and orthopedic interventions. Patients were relatively healthy, sedated and relaxed, monitored and with venous access, in optimal hemodynamic and ventilatory conditions, and no reaction during insertion of the device was seen. The result of this study in humans reaffirmed the indication of the supraglottic devices because of the shorter time of application $^{(30)}$. Both studies on manikins and humans pointed to the same technology in their results, although it has to be careful considering an important bias between manikin and human studies by methodological limitations and different settings.

It is also worth noting that study participants assisted one manikin at a time; did not observe an oral cavity with secretions; there were no conditions of multiple injuries, convulsions or hypoxia. Such a description is inconsistent with real interventions to victims in open respiratory distress due to chemical, biological or radiological agents in the context of multiple casualty accidents where the objective is to provide a safe airway for as many victims as possible so as to increase the chances of survival. After all, time to airway installation is a crucial factor for survival and stabilization of the physically compromised, unconscious, dyspneic victim, with increased airway secretions and hypoxemia ${ }^{(9,34)}$.

Corroborating the above, all studies were performed in a laboratory, i.e., indoors, with optimal brightness, controlled temperature and using manikins, which may not reflect reality ${ }^{(9-10,34)}$. This systematic review reaffirmed the lack prospective or retrospective studies on this subject with humans, as exposed by other researchers in the area ${ }^{(10)}$. It is worth mentioning that this review was made with observational studies. The randomized clinical trials have accuracy to demonstrate efficacy of interventions. On the other hand, considering that both the studies on manikins and in humans pointed to the effectiveness of supraglottic devices in reducing implementation time, there is a reasonable degree of legitimacy to the conclusions and recommendations made here.

Complementarily, when the nine studies for global analysis were associated, the figures of 399 participants and 812 performances with supraglottic devices and orotracheal tube were reached. Figure 4 shows 792 performances for the orotracheal tube, computing only successful attempts.

\section{Contributions to the Field}

At the biological, chemical and radiological disasters, shortterm interventions have to be aimed at saving lives, such as airway management. Time reducing to implement the ventilatory support technique directly impacts the survival of victims in respiratory failure in a tragic setting.

Thus, this analysis provides support for decision-making by healthcare providers about which technology to use as a priority based on effectiveness of airway management devices. In general, laryngeal masks are transitory devices that are followed by tracheal intubation to prevent bronchoaspiration risk.

Furthermore, it is worth mentioning the authorization for nurses trained with insertion of supraglottic devices by Federal Nursing Council (Brazil), through official statement $n^{\circ} 1 / 2015^{(35)}$ in case of emergency. In this sense, in a setting of emergencies and disasters involving biological, chemical or radiological agents, the range of professional performance in airway management in the care of victims in respiratory failure is reaffirmed.

It is worth mentioning that there were two studies whose main author was an English nurse ${ }^{(23-24)}$, with 139 health providers from different professions performing 278 times supraglottic devices, 
and 258 times the orotracheal tube. This represents $34.25 \%$ of the supraglottic device data and $32.57 \%$ of the orotracheal tube data for meta-analyzes. Such information reiterates the importance of this theme for healthcare, including nursing care practices in emergencies and disasters.

\section{CONCLUSION}

The systematic review indicates supraglottic devices as being of faster application in detriment of orotracheal intubation, with the result of reduced time to perform ventilatory support techniques in view of the heterogeneity found. Analysis by subgroups showed uniformity of performance among healthcare providers working in the emergency and surgery settings. Furthermore, the methodological reproduction was a major factor to obtain homogeneous results, and the professional class or the ventilatory support device employed had little influence on this.
Thus, studies with manikins, with moderate level of evidence, allowed the recommendation of supraglottic devices as the first choice in chemical, biological or radiological disasters where management of a contaminated airway is required. After stabilizing patients and considering a greater supply of professionals and material, the supraglottic device can be replaced by the orotracheal tube.

This outcome is important because it impacts the survival of victims in respiratory failure and provides preliminary support for decision-making by healthcare providers, as to which technology should be primarily used in view of shorter time of application.

According to the GRADE system, there is a moderate quality of evidence favoring supraglottic devices.

Despite the advances and indication that the systematic review provided with a moderate level of evidence, given the unprecedented character of this systematic review, further studies with better methodological quality and more robustness are required to achieve a recommendation with high level of evidence.

\section{REFERENCES}

1. Tokuda Y, Kikuchi M, Takahashi O, Stein GH. Prehospital management of sarin nerve gas terrorism in urban settings: 10 years of progress after the Tokyo subway sarin attack. Resuscitation. 2006;68(2):193-202. https://doi.org/10.1016/j.resuscitation.2005.05.023

2. Rothan HA, Byrareddy SN. The epidemiology and pathogenesis of coronavirus disease (COVID-19) outbreak. J Autoimmun. 2020;102433. https://doi.org/10.1016/j.jaut.2020.102433

3. Ranney ML, Griffeth V, Jha AK. Critical Supply Shortages-The Need for Ventilators and Personal Protective Equipment during the Covid-19 Pandemic. N Engl J Med. 2020;382:e41. https://doi.org/10.1056/NEJMp2006141

4. Lai C-C, Shih T-P, Ko W-C, Tang H-J, Hsueh P-R. Severe acute respiratory syndrome coronavirus 2 (SARS-CoV-2) and coronavirus disease-2019 (COVID-19): the epidemic and the challenges. Int J Antimicrob Agents. 2020;105924. https://doi.org/10.1016/j.ijantimicag.2020.105924

5. Gale RP, Armitage JO, Hashmi SK. Emergency response to radiological and nuclear accidents and incidents. Br J Haematol. 2019;192(6):96872. https://doi.org/10.1111/bjh.16138

6. Anderson JL, Failla G, Finklea LR, Charp P, Ansari AJ. Radiation exposure of workers and volunteers in shelters and community reception centers in the aftermath of a nuclear detonation. Health Phys. 2019;116(5):619-24. https://doi.org/10.1097/HP.0000000000000987

7. Malich G, Coupland R, Donnelly S, Baker D. A proposal for field-level medical assistance in an international humanitarian response to chemical, biological, radiological or nuclear events. Emerg Med J. 2013;30(10):804-8. https://doi.org/10.1136/emermed-2012-201915

8. Udayasiri R, Knott J, McD Taylor D, Papson J, Leow F, Hassan FA. Emergency department staff can effectively resuscitate in level C personal protective equipment. Emerg Med Australas. 2007;19(2):113-21. https://doi.org/10.1111/j.1742-6723.2007.00918.x

9. Garner A, Laurence $H$, Lee A. Practicality of performing medical procedures in chemical protective ensembles. Emerg Med Australas. 2004;16(2):108-13. https://doi.org/10.1111/j.1742-6723.2004.00560.x

10. Rodgers Jr GC, Condurache CT. Antidotes and treatments for chemical warfare/terrorism agents: an evidence-based review. Clin Pharmacol Ther. 2010;88(3):318-27. https://doi.org/10.1038/clpt.2010.152

11. Gordon J, Cooper RM, Parotto M. Supraglottic airway devices: indications, contraindications and management. Minerva Anestesiol. 2018;84(3):389-97. https://doi.org/10.23736/S0375-9393.17.12112-7

12. Scott Taylor R, Pitzer M, Goldman G, Czysz A, Simunich T, Ashurst J. Comparison of intubation devices in level C personal protective equipment: a cadaveric study. Am J Emerg Med. 2018;36(6):922-5. https://doi.org/10.1016/j.ajem.2017.10.047

13. Bosc J, Sanchez O, Carrie C, Revel P, Tentillier E, Biais M, et al. Faisabilité des gestes d'urgence en tenue de protection individuelle du virus Ebola: pose d'abords vasculaires et contrôle des voies aériennes supérieures sur mannequin. Ann Fr Med Urgence. 2016;6(3):172-8. https:// doi.org/10.1007/s13341-016-0631-2

14. Kim TH, Kim CH, Shin SD, Haam S. Influence of personal protective equipment on the performance of life-saving interventions by emergency medical service personnel. Simulation. 2016;92(10):893-8. https://doi.org/10.1177/0037549716662322

15. Plazikowski E, Greif R, Marschall J, Pedersen TH, Kleine-Brueggeney M, Albrecht R, et al. Emergency airway management in a simulation of highly contagious isolated patients: both isolation strategy and device type matter. Infect Control Hosp Epidemiol. 2018;39(2):145-51. https://doi.org/10.1017/ice.2017.287

16. Wang CC, Chaou CH, Tseng CY, Lin CC. The effect of personal protective equipment on emergency airway management by emergency physicians: a mannequin study. Eur J Emerg Med. 2016;23(2):124-9. https://doi.org/10.1097/MEJ.0000000000000157 
17. Castle N, Pillay Y, Spencer N. Insertion of six different supraglottic airway devices whilst wearing chemical, biological, radiation, nuclearpersonal protective equipment: a manikin study. Anaesthesia. 2011;66(11):983-8. https://doi.org/10.1111/j.1365-2044.2011.06816.x

18. McHugh ML. Interrater reliability: the kappa statistic. Biochem Med [Internet]. 2012[cited 2019 Oct 24];22(3):276-82. Available from: https:// hrcak.srce.hr/89395

19. Sterne JAC, Hernán MA, Reeves BC, Savović J, Berkman ND, Viswanathan M, et al. ROBINS-l: a tool for assessing risk of bias in nonrandomised studies of interventions. BMJ. 2016;355:i4919. https://doi.org/10.1136/bmj.i4919

20. Borenstein M, Higgins JPT, Hedges LV, Rothstein HR. Basics of meta-analysis: I2 is not an absolute measure of heterogeneity. Res Synth Methods. 2017;8(1):5-18. https://doi.org/10.1002/jrsm.1230

21. Brożek JL, AkI EA, Alonso-Coello P, Lang D, Jaeschke R, Williams JW, et al. Grading quality of evidence and strength of recommendations in clinical practice guidelines: part 1 of 3 . An overview of the GRADE approach and grading quality of evidence about interventions. Allergy. 2009;64(5):669-77. https://doi.org/10.1111/j.1398-9995.2009.01973.x

22. Ben-Abraham R, Weinbroum AA. Laryngeal mask airway control versus endotracheal intubation by medical personnel wearing protective gear. Am J Emerg Med. 2004;22(1):24-6. https://doi.org/10.1016/j.ajem.2003.09.006

23. Castle N, Owen R, Hann M, Clark S, Reeves D, Gurney I. Impact of Chemical, Biological, Radiation, and Nuclear Personal Protective Equipment on the performance of low- and high-dexterity airway and vascular access skills. Resuscitation. 2009;80(11):1290-5. https://doi. org/10.1016/j.resuscitation.2009.08.001

24. Castle N, Owen R, Clarke S, Hann M, Reeves D, Gurney I. Does position of the patient adversely affect successful intubation whilst wearing CBRN-PPE? Resuscitation. 2010;81(9):1166-71. https://doi.org/10.1016/j.resuscitation.2010.05.009

25. Greenland KB, Tsui D, Goodyear P, Irwin MG. Personal protection equipment for biological hazards: does it affect tracheal intubation performance? Resuscitation. 2007;74(1):119-26. https://doi.org/10.1016/j.resuscitation.2006.11.011

26. Ophir N, Ramaty E, Rajuan-Galor I, Rosman Y, Lavon O, Shrot S, et al. Airway control in case of a mass toxicological event: superiority of second-generation supraglottic airway devices. Am J Emerg Med. 2014;32(12):1445-9. https://doi.org/10.1016/j.ajem.2014.08.067

27. Weaver KR, Barr GC, Long KR, Diaz L, Ratner AS, Reboul JP, et al. Comparison of airway intubation devices when using a biohazard suit: a feasibility study. Am J Emerg Med. 2015;33(6):810-4. https://doi.org/10.1016/j.ajem.2015.02.051

28. Claret PG, Bobbia X, Asencio R, Sanche E, Gervais E, Roger C, et al. Comparison of the Airtraq laryngoscope versus the conventional Macintosh laryngoscope while wearing CBRN-PPE. Eur J Emerg Med. 2016;23(2):119-23. https://doi.org/10.1097/MEJ.0000000000000220

29. Godavitarne C, Robertson A, Ricketts DM, Rogers BA. Understanding and interpreting funnel plots for the clinician. Br J Hosp Med. 2018;79(10):578-83. https://doi.org/10.12968/hmed.2018.79.10.578

30. Flaishon R, Sotman A, Ben-Abraham R, Rudick V, Varssano D, Weinbroum AA. Anti Chemical protective gear prolongs time to successful airway management: a randomized, crossover study in humans. Anesthesiol. 2004;100(2):260-6. https://doi.org/10.1097/00000542-200402000-00013

31. Goldik Z, Bornstein J, Eden A, Ben-Abraham R. Airway management by physicians wearing anti-chemical warfare gear: comparison between laryngeal mask airway and endotracheal intubation. Eur J Anaesthesiol. 2002;19(3):166-9. https://doi.org/10.1017/S0265021502000297

32. Schröder H, Zoremba N, Rossaint R, Deusser K, Stoppe C, Coburn M, et al. Intubation performance using different laryngoscopes while wearing chemical protective equipment: a manikin study. BMJ Open. 2016;6(3):e010250. https://doi.org/10.1136/bmjopen-2015-010250

33. Higgins JPT, Thompson SG, Deeks JJ, Altman DG. Measuring inconsistency in meta-analyses. BMJ. 2003;327(7414):557-60. https://doi. org/10.1136/bmj.327.7414.557

34. Schumacher J, Arlidge J, Garnham F, Ahmad I. A randomised crossover simulation study comparing the impact of chemical, biological, radiological or nuclear substance personal protection equipment on the performance of advanced life support interventions. Anaesthesia. 2017;72(5):592-7. https://doi.org/10.1111/anae.13842

35. Conselho Federal de Enfermagem (COFEN). Comitê Excelência, Renovação, Inovação e Segurança do Cuidar. Parecer técnico n $1 / 2015$, de 25 de novembro de 2015. Utilização e manuseio de dispositivos supraglóticos e infraglóticos de vias aéreas avançadas, traqueostomia e cricotireoideostomia por enfermeiro [Internet]. 2015 [cited 2019 Sep 13] Available from: http://www.cofen.gov.br/parecer-no012015cofencomite-excelencia-renovacao-inovacao-e-seguranca-do-cuidar_37797.html 